\author{
Volcanoes of the Passive Margin: \\ The youngest magmatic event in Eastern North America
}

\title{
DR1. Methods
}

Rock samples were collected from dikes, plugs and diatremes in VA and WV (locations shown in Fig. 1 and Table DR1). ${ }^{40} \mathrm{Ar} /{ }^{39} \mathrm{Ar}$ ages were determined the U.S. Geological Survey (USGS) in Reston, VA for four amphibole and one whole rock matrix samples. The amphibole samples were prepared using standard mineral separation techniques described by Kunk and McAleer (2011) to a purity of greater than 99.9 percent. The whole rock sample was processed using the same techniques to remove phenocrysts from the matrix and concentrate the ground mass. Samples were irradiated in two packages (KD55 \& KD57) in the central thimble facility at the TRIGA reactor (GSTR) at the U.S.G.S., in Denver, CO. The monitor mineral used in both packages was FCT-3 sanidine with an age of 27.79 Ma (Kunk et al., 1985; Cebula et al., 1986) relative to MMhb-1 at $519.4 \pm 2.5$ Ma (Alexander et al., 1978; and Dalrymple et al., 1981). Following irradiation the samples were analyzed at the USGS in Reston, VA. The samples were heated in a small volume, molybdneum-lined, low-blank tantalum resistance furnace similar to that described by Staudacher (1978). After the gases from the samples were cleaned, the samples were then analyzed using a VG $1200 \mathrm{~B}$ or a MAP 216 mass spectrometer. Data reduction was done using updated versions of the computer programs ArAr* (Haugerud and Kunk, 1988), and Mass spec (Deino, 2001) respectively. Plateau ages were determined using the definition of Fleck, et al. (1977) as modified by Haugerud and Kunk (1988). Inverse isotope correlation analysis of the analytical data to assess if non-atmospheric argon components were trapped in any samples and to calculate an inverse isochron age was done using the method of York (1969). All stated analytical uncertainties are $1 \sigma$. Uncertainties for the individual step ages do not include the uncertainties in the irradiation parameter " $\mathrm{J}$ ", uncertainties for the production of interfering isotopes produced during neutron irradiation, or the uncertainty in the age of the monitor mineral. Only plateau and isochron ages include the uncertainty in the irradiation parameter "J". A more detailed description of the analytical and data reduction techniques can be found in Kunk and McAleer (2011), Hagarud and Kunk (1988), and Deino (2001)

Alteration-free rock chips of sample matrices (to exclude any xenocrysts or xenoliths) were selected under stereoscope microscope. These chips were powdered in an alumina mill and then fluxed into homogeneous glass disks with ultrapure $\mathrm{Li}_{2} \mathrm{~B}_{4} \mathrm{O}_{7}$ from $\operatorname{Spex}{ }^{\circledR}$ (certified $<<1$ ppm blank for all trace elements) at the Petrology Lab at Virginia Tech for XRF and ICP-MS analyses. Major element geochemistry was collected with a Panalytical EDS-XRF with a silicon detector at the department of Geosciences at Virginia Tech. The accuracy for USGS standard BHVO-2g (run as an unknown) was better than $1.5 \%$ for most major elements but $\mathrm{Na}_{2} \mathrm{O}, \mathrm{K}_{2} \mathrm{O}$, and $\mathrm{P}_{2} \mathrm{O}_{5}$ that was better than $8 \%$ within reported values. The average RSD for 10 replicates of BHVO-2g were $<1.6 \%$ for all major elements. Trace elements from fluxed glasses were collected with an Agilent 7500ce ICPMS coupled with a Geolas laser ablation system following the procedures detailed in Kelley et al. (2003) and Gazel (2012), with a He flow rate $\sim 1 \mathrm{~L} / \mathrm{m}-5 \mathrm{~Hz}$ and an energy density on sample $\sim 7-10 \mathrm{~J} / \mathrm{cm}^{2}$. Sample data were 
calibrated against fluxed glasses of USGS standards BHVO-2g, BCR-2g, and BIR-1g, using Ti from XRF as an internal standard and the standard values from Kelley et al. (2003). The average relative accuracy for 10 replicates of BHVO-2g (run as an unknown) was better than 5\% for most trace elements except Rb, Sr, Sn, Yb, and Th (better than 15\%). The average precision for BHVO-2g was a RSD $<5 \%$ for all elements with the exception of Ni, Cu, Gd, Yb, Lu, and Th $(<7 \%$,).

We measured radiogenic isotope ratios at the University of North Carolina (UNC) and at the Center for Elemental Mass Spectrometry (CEMS), University of South Carolina (USC). Isotopic ratios for $\mathrm{Pb}, \mathrm{Nd}$, and $\mathrm{Sr}$ were obtained on the VG Sector 54 thermal ionization mass spectrometer at UNC following procedures highlighted in Gray et al. (2008), and on a Neptune multi collector ICPMS at USC. Mass fractionation correction of $0.12 \% / a m u$ as determined by replicate analyses of NBS-981 was used for Pb isotopic ratios on the TIMS. At CEMS/USC $\mathrm{Pb}$ isotope ratios were determined by the TI-addition technique (White et al., 2000). The NBS-981 was determined at ${ }^{206} \mathrm{~Pb} /{ }^{204} \mathrm{~Pb}=16.936 \pm 0.001,{ }^{207} \mathrm{~Pb} /{ }^{204} \mathrm{~Pb}=15.490 \pm 0.001$, ${ }^{208} \mathrm{~Pb} /{ }^{204} \mathrm{~Pb}=36.694 \pm 0.003$ (2 standard deviations, = 13). Isotopic ratios for Nd were normalized to ${ }^{146} \mathrm{Nd} /{ }^{144} \mathrm{Nd}=0.7219$ and the $\mathrm{Nd}$ standard JNdi was measured at ${ }^{143} \mathrm{Nd} /{ }^{144} \mathrm{Nd}=$ 0.5121 and $0.512112 \pm 0.000007(\mathrm{n}=6)$ at USC. Isotopic ratios for $\mathrm{Sr}$ were normalized to ${ }^{86} \mathrm{Sr} /{ }^{88} \mathrm{Sr}=0.1194$ and replicate analyses of standard NBS-987 yielded ${ }^{87} \mathrm{Sr} /{ }^{86} \mathrm{Sr}=0.710258$ at UNC and $0.710320 \pm 0.000012$ at USC. All Sr measurements are reported relative to NBS-987 ${ }^{87} \mathrm{Sr} /{ }^{86} \mathrm{Sr}=0.710250$.

\section{DR2. Detailed Description of ${ }^{40} \mathrm{Ar} /{ }^{39} \mathrm{Ar}$ Results}

The age spectra from the four dated amphibole samples are of variable quality. Age spectra of samples 12DJHQ1 and DRBB-66 (Figure DR1A and DR1B and Table DR2) both yielded plateau ages containing a large majority of gas (95 and $76 \%$ ) in each sample at $47.0 \pm$ 0.2 and $47.9 \pm 0.2$ Ma respectively. Inverse isotope correlation analysis of the age spectrum data (Figure $1 \mathrm{~A} \& \mathrm{~B}$ ) resulted in virtually identical ages $(47.1 \pm 1.2$ and $47.8 \pm 0.3 \mathrm{Ma})$ with acceptable MSWD (0.178 and 2.4) and atmospheric initial ${ }^{40} \mathrm{Ar} /{ }^{36} \mathrm{Ar}$ ratios (308 \pm 9 and $304 \pm$ 11). The age spectrum of sample 12DJ631D1 did not yielded an age plateau, but except for the first release step, the spectrum is essentially flat and has an average age of $46.9 \pm 0.2 \mathrm{Ma}$. Inverse isotope correlation analysis of the age spectrum data (Figure DR1C, Table DR2) results in an apparent age of $46.9 \pm 0.2$ Ma with $\mathrm{MSWD}=0.1$ and an atmospheric initial ${ }^{40} \mathrm{Ar} /{ }^{36} \mathrm{Ar}$ ratio $(293 \pm 293 \pm 31)$. The age spectrum of amphibole sample 12DJ631C, did not yield an age plateau and is quite disturbed in the upper temperature steps climbing to ages as high as $68 \mathrm{Ma}$. Inverse isotope correlation analysis of the data from this sample did not produce a useful age (Figure DR1D, Table DR2).

The plateau ages of amphibole samples 12DJHQ1 and DRBB-66 give the most precise results of the samples analyzed and are interpreted to represent the time of dike emplacement. However, their ages are not the same within the limits of error when tested using the critical value test of Dalrymple and Lanphyre (1969, p. 120) suggesting that the emplacement of the Eocene dikes may have occurred over an interval of about $1 \mathrm{Ma}$ from about 47.9 $\pm 0.2 \mathrm{Ma}$ to $47.0 \pm 0.2$ Ma. The $46.9 \pm 0.2$ average and inverse isotope correlation of amphibole of sample 12DJ631D1 while of somewhat lesser quality strongly support the younger end of this age range. 
These ages fall within the range of previously published K/Ar data (Southworth et al., 1993), but are considerably more precise.

The age spectrum of basaltic matrix from sample Trimble Knob A was somewhat disturbed and did not yield an age plateau (Figure DR1E, Table DR2). Inverse isotope correlation analysis also failed to resolve an age for this sample. Nonetheless, the individual step ages for this sample range in age from 50.1 Ma to 46.4 Ma with a total gas age of 48.2 Ma. This age is the same as those of three of the amphiboles discussed above, but is about 12-13 Ma older than a K/Ar age reported by Southworth et al., (1993) for a sample collected from the same outcrop. This large difference in age together with the lack of any other ages in the younger 35 Ma range strongly suggests that the data for their sample from Trimble Knob is in error.

\section{DR3. Petrological Modeling}

Determining the source lithology of a suite of magmatic samples is not only important for the overall geotectonic interpretation of the magma genesis, but it is crucial to petrological modeling based on parameterization of experimental data and observations made on mantle peridotite sources. In recent years, the development of new petrological methods based on major element geochemistry (eg., Sobolev et al., 2005; Herzberg and Asimow, 2008; Dasgupta et al., 2007) provided new insights for the composition of magma source lithology. Finally, constraining magma oxidation state is fundamental to calculating primary compositions in equilibrium with the melting mantle source as the proportion of $\mathrm{Fe}^{3+} \mathrm{Fe}^{2+}$, as only $\mathrm{Fe}^{2+}$ strongly affects olivine-melt equilibrium modeling.

In order to calculate the melting condition that produced the Eocene magmatic event in the ENAM, we used the thermobarometer developed by Lee et al. (2009) to produce primary magmas compositions and model the temperature and pressure of the melting regime. The thermometer in this model is based on olivine-melt Fe-Mg exchange, while the barometer is based on Si activity in melts in equilibrium with orthopyroxene+olivine. To use this thermobaromer, samples must be olivine controlled (as verified by major element geochemistry and petrographic studies). Olivine was then added by an incrementally calculation (using a constant $\mathrm{K}_{\mathrm{D}}=0.3$ for the $\mathrm{Fe}^{2+/} \mathrm{Mg}$ exchange) until the melts reached equilibrium with mantle olivine (assumed to be $\mathrm{Fo}_{90}$ ). For the $\mathrm{H}_{2} \mathrm{O}$ content, we used $1 \mathrm{wt} \% \mathrm{H}_{2} \mathrm{O}$ from Sacco et al. (2011) and we assumed $0.15 \mathrm{Fe}^{3+}$ as suggested by Kelley and Cottrell (2009) for samples with $1 \mathrm{wt} \%$ $\mathrm{H}_{2} \mathrm{O}$. An uncertainty of $1 \mathrm{wt} \% \mathrm{H}_{2} \mathrm{O}$ introduces a temperature uncertainty of $20^{\circ} \mathrm{C}$; and $10 \%$ $\mathrm{Fe}^{3+} / \mathrm{Fe}_{\mathrm{T}}$ of $40^{\circ} \mathrm{C}$ and $0.3 \mathrm{GPa}$.

After this we used the $\mathrm{CaO}-\mathrm{MgO}-\mathrm{SiO} 2$ composition of the primary magmas following the model proposed by Herzberg (2010) and Gazel et al. (2011) to determine if the samples were produced by melting a peridotite source. Once the primary magmas from a peridotite source were determined, we calculated the mantle potential temperature in ${ }^{\circ} \mathrm{C}$, with the following equation $\mathrm{T}_{\mathrm{P}}=1463+12.74 * \mathrm{MgO}-2924 / \mathrm{MgO}$ (Herzberg and Asimow, 2008). The $\mathrm{T}_{\mathrm{P}}$ uncertainty is $\sim 60{ }^{\circ} \mathrm{C}$ (Herzberg and Gazel, 2009), making calculated $\mathrm{T}_{\mathrm{P}}$ (reported in Table DR1) within the range of ambient mantle or slightly elevated than ambient mantle (e.g. Putirka, 2005; McKenzie et al., 2005; Herzberg et al., 2007). Finally, for the set of samples used in this study we found negative correlation between $\mathrm{Gd} / \mathrm{Yb}$ (ratio fractionated by garnet in the source during melting) 
and pressure of equilibration (Figure DR2). This is consistent with an increase in the modal abundance of garnet in the mantle source with increasing pressure (e.g., Johnson, 1998), independently supporting the pressure estimates.

\section{DR4. Assessment of Crustal Interaction}

In order to evaluate if the radiogenic signatures found in the Eocene VA intraplate magmas (Fig. 3 main text, Table DR1) are related to mantle sources and not crustal contamination, we produced an assessment of crustal interaction. To do this we compiled all the available isotopic compositions for the local Blue Ridge crustal basement. The crustal endmembers include gneisses, diorites-granites, and charnokites from Pettingill et al. (1984) and Sinha et al. (1996). These samples are corrected to the average eruptive age of the VA Eocene magmatism 50Ma (Fig. DR3). To estimate the effect of depleted mantle sources we included local MORB samples, collected offshore from the VA Eocene magmas (Janney et al., 2001). Finally we produced assimilation-fractional crystallization modeling (AFC, DePaolo, 1981) with our end-member sample TK5 and a representative crustal end-member (Fig. DR3). For TK5, we used a modal composition of $30 \%$ olivine $+30 \%$ clinopyroxene $+40 \%$ plagioclase determined as CIPW norm of the primary magma composition in equilibrium with mantle (Fo90) and the partition coefficients compiled by Rollinson (1993), and Pb from McKenzie and O'Nions (1991).

In terms of $\mathrm{Pb}$ isotopes the local Blue Ridge crust is surprisingly unradiogenic $\left({ }^{206} \mathrm{~Pb} /{ }^{204} \mathrm{~Pb}<17.6 ;{ }^{207} \mathrm{~Pb} /{ }^{206} \mathrm{~Pb} 15.52-15.65 ;{ }^{208} \mathrm{~Pb} /{ }^{204} \mathrm{~Pb} 36.5-37.5\right.$, Fig. DR3). This is clear evidence that the $\mathrm{Pb}$ isotopes signatures are not controlled by crustal contamination, and if anything, will produce less radiogenic magmas. AFC modeling failed to explain the Pb-data array of the Eocene magmas. Thus, the Pb-isotopes compositions are more consistent of mixing of MORB (Depleted Mantle) and HIMU sources (Figs. DR3A and DR3B). Although, Srisotopes from the VA samples may be controlled by crustal interaction by some degree, they are also within the range of expected mantle values from other Atlantic intraplate settings (Fig. 3, main text), explained by mixing of MORB and HIMU sources (Fig. DR3C). Finally, the Ndisotopes from four of our VA Eocene samples can be explained by AFC modeling (Fig. DR3D). Nevertheless, it is important to keep in mind that similar Nd-isotopes compositions have been found in the Cape Verde Archipelago (Fig. 3, main text). The rest of the samples can be explained by mixing of MORB and HIMU sources, consistent with the results of $\mathrm{Pb}$ and $\mathrm{Sr}$ systems.

\section{References}

Alexander, E.C., Jr., Mickelson, G.M., and Lanphere, M.A., 1978, Mmhb-1: a new ${ }^{40} \mathrm{Ar} /{ }^{39} \mathrm{Ar}$ dating standard, in Zartman, R.E., ed., Short papers of the fourth international conference, geochronology, cosmochronology, and isotope geology 1978: U.S. Geological Survey Open-File Report 78-701, p. 6-8.

Cebula, G.T., Kunk, M.J., Mehnert, H.H., Naeseer, C.W., Obradovich, J.D., and Sutter, J.F., 1986, The Fish Canyon tuff, a potential standard for the ${ }^{40} \mathrm{Ar} /{ }^{39} \mathrm{Ar}$ and fission track dating methods: Terra Cognita, v. 6, p. 140. 
Dalrymple, G.B., Alexander, E.C., Lanphere, M.A., and Kraker, G.P., 1981, Irradiation of samples for ${ }^{40} \mathrm{Ar} /{ }^{39} \mathrm{Ar}$ dating using the Geological Survey TRIGA reactor: U.S. Geol. Survey Professional Paper 1176, 55 p.

Dalrymple, G.B., and Lanphere, M.A., 1969, Potassium-Argon dating principals techniques and applications to geochronology: W.H. Freeman and Company, 258 p.

Dasgupta, R., Hirschmann, M.M., and Smith, N.D., 2007, Partial melting experiments of peridotite+ $\mathrm{CO} 2$ at $3 \mathrm{GPa}$ and genesis of alkalic ocean island basalts: Journal of Petrology, v. 48, no. 11, p. 2093-2124, doi:10.1093/petrology/egm053.

Deino, A.L., 2001, User’s manual for Mass Spec v. 5.02: Berkeley Geochronology Center Special Publication 1a, 119 p.

DePaolo, D., 1981, Trace element and isotopic effects of combined wallrock assimilation and fractional crystallization: Earth and Planetary Science Letters, v. 53, p. 189-202, doi:10.1016/0012-821X(81)90153-9.

Fleck, R.J., Sutter, J.F., and Elliot, D.H., 1977, Interpretation of discordant ${ }^{40} \mathrm{Ar} /{ }^{39} \mathrm{Ar}$ age spectra of Mesozoic tholeiites from Antarctica: Geochimica et Cosmochimica Acta, v. 41, p. 1532, doi:10.1016/0016-7037(77)90184-3.

Gazel, E., Hoernle, K., Carr, M.J., Herzberg, C., Saginor, I., den Bogaard, P.v., Hauff, F., Feigenson, M., and Swisher, C., 2011, Plume-subduction interaction in southern Central America: Mantle upwelling and slab melting: Lithos, v. 121, p. 117-134, doi:10.1016/j.lithos.2010.10.008.

Gazel, E., Plank, T., Forsyth, D.W., Bendersky, C., Lee, C.T.A., and Hauri, E.H., 2012, Lithosphere versus asthenosphere mantle sources at the Big Pine Volcanic Field, California: Geochemistry Geophysics Geosystems, v. 13, doi:10.1029/2012GC004060.

Gray, W., Glazner, A.F., Coleman, D.S., and Bartley, J.M., 2008, Long-term geochemical variability of the Late Cretaceous Tuolumne intrusive suite, central Sierra Nevada, California: Geological Society of London, Special Publications, v. 304, p. 183-201, doi:10.1144/SP304.10.

Haugerud, R.A., and Kunk, M.J., 1988, ArAr*, a computer program for reduction of ${ }^{40} \mathrm{Ar}-{ }^{39} \mathrm{Ar}$ data: U.S. Geological Survey Open-File Report 88-261, 68 p.

Herzberg, C., 2010, Identification of Source Lithology in the Hawaiian and Canary Islands: Implications for Origins: Journal of Petrology, v. 52, p. 113-146, doi:10.1093/petrology/egq075.

Herzberg, C., Asimow, P.D., Arndt, N., Niu, Y., Lesher, C.M., Fitton, J.G., Cheadle, M.J., and Saunders, A.D., 2007, Temperatures in ambient mantle and plumes: Constraints from basalts, picrites, and komatiites: Geochemistry Geophysics Geosystems, v. 8, doi:10.1029/2006GC001390.

Herzberg, C., and Asimow, P.D., 2008, Petrology of some oceanic island basalts: PRIMELT2. XLS software for primary magma calculation: Geochemistry Geophysics Geosystems, v. 9, doi:10.1029/2008GC002057.

Janney, P., and Castillo, P., 2001, Geochemistry of the oldest Atlantic oceanic crust suggests mantle plume involvement in the early history of the central Atlantic Ocean: Earth and Planetary Science Letters, v. 192, p. 291-302, doi:10.1016/S0012-821X(01)00452-6.

Johnson, K.T., 1998, Experimental determination of partition coefficients for rare earth and highfield-strength elements between clinopyroxene, garnet, and basaltic melt at high pressures: Contributions to Mineralogy and Petrology, v. 133, p. 60-68, doi:10.1007/s004100050437. 
Kelley, K.A., and Cottrell, E., 2009, Water and the oxidation state of subduction zone magmas: Science, v. 325, p. 605-607, doi:10.1126/science.1174156.

Kelley, K.A., Plank, T., Ludden, J., and Staudigel, H., 2003, Composition of altered oceanic crust at ODP Sites 801 and 1149: Geochemistry Geophysics Geosystems, v. 4, doi:10.1029/2002GC000435.

Kunk, M.J., and McAleer, R., 2011, ${ }^{40} \mathrm{Ar} /{ }^{39} \mathrm{Ar}$ Age-spectrum data for hornblende, biotite, white mica, and K-feldspar samples from metamorphic rocks in the Great Smokey Mountains of North Carolina and Tennessee: U.S. Geological Survey Open-File Report 2011-1250, 56 p.

Kunk, M.J., Sutter, J.F., and Naeser, C.W., 1985, High-precision ${ }^{40} \mathrm{Ar} /{ }^{39} \mathrm{Ar}$ Ages of Sanidine, Biotite, Hornblende, and Plagioclase From the Fish Canyon Tuff, San Juan Volcanic Field, South-central Colorado: Geological Society of America Abstracts with Programs, v. 17, p. 636.

Lee, C.T.A., Luffi, P., Plank, T., Dalton, H., and Leeman, W.P., 2009, Constraints on the depths and temperatures of basaltic magma generation on Earth and other terrestrial planets using new thermobarometers for mafic magmas: Earth and Planetary Science Letters, v. 279, no. 1, p. 20-33, doi:10.1016/j.epsl.2008.12.020.

McKenzie, D., Jackson, J., and Priestley, K., 2005, Thermal structure of oceanic and continental lithosphere: Earth and Planetary Science Letters, v. 233, p. 337-349, doi:10.1016/j.epsl.2005.02.005.

McKenzie, D., and O'nions, R.K., 1991, Partial melt distributions from inversion of rare earth element concentrations: Journal of Petrology, v. 32, p. 1021-1091, doi:10.1093/petrology/32.5.1021.

Pettingill, H.S., Sinha, A.K., and Tatsumoto, M., 1984, Age and origin of anorthosites, charnockites, and granulites in the Central Virginia Blue Ridge: Nd and Sr isotopic evidence: Contributions to Mineralogy and Petrology, v. 85, p. 279-291, doi:10.1007/BF00378106.

Putirka, K.D., 2005, Mantle potential temperatures at Hawaii, Iceland, and the mid-ocean ridge system, as inferred from olivine phenocrysts: Evidence for thermally driven mantle plumes: Geochemistry Geophysics Geosystems, v. 6, doi:10.1029/2005GC000915.

Rollinson, H., 1993, Using geochemical data: evaluation, presentation, interpretation: New York, John Wiley \& Sons, Inc. p. 52-61.

Sacco, B., Johnson, E.A., and Belkin, H.E., 2011, Depth and temperature of the mantle beneath Mole Hill, an Eocene basalt near Harrisonburg, VA: Geological Society of America Abstracts with Programs, v. 43, p. 155.

Sinha, A.K., Hogan, J.P., and Parks, J., 1996, Lead isotope mapping of crustal reservoirs within the Grenville superterrane: I. Central and Southern Appalachians: Earth Processes: Reading the Isotopic Code, v. 95, p. 293-305, doi:10.1029/GM095p0293.

Sobolev, A.V., Hofmann, A.W., Sobolev, S.V., and Nikogosian, I.K., 2005, An olivine-free mantle source of Hawaiian shield basalt: Nature, v. 434, p. 590-597, doi:10.1038/nature03411.

Southworth, C.S., Gray, K., and Sutter, J.F., 1993, Middle Eocene Intrusive Igneous Rocks of the Central Appalachian Valley and Ridge Province: Setting, Chemistry and Implications for Crustal Structure.

Staudacher, T., Jessberger, E.K., Dorflinger, D., and Kilko, J., 1978, A refined ultrahigh-vacuum furnace for rare gas analysis: Journal of Physics. E, Scientific Instruments, v. 11, p. 781784, doi:10.1088/0022-3735/11/8/019. 
White, W.M., Albarede, F., and Telouk, P., 2000, High-precision analysis of Pb isotope ratios by multi-collector ICP-MS: Chemical Geology, v. 167, p. 257-270, doi:10.1016/S00092541(99)00182-5.

York, D., 1969, Least squares fitting of a straight line with correlated errors: Earth and Planetary Science Letters, v. 5, p. 320-324, doi:10.1016/S0012-821X(68)80059-7.

\section{FIGURE CAPTIONS}

Figure DR1: Age spectra and isochrons for ${ }^{40} \mathrm{Ar} /{ }^{39} \mathrm{Ar}$ age dating. (a) 12DJHQ1 (b) DRBB-66 (c) 12DJ631D1 (d) 12DJ631C (e) Trimble Knob A.

Figure DR2: Gd/Yb (HREE fractionation) as a function of equilibration pressure (Section S3) suggesting an increase in modal garnet in the residue of the deeper equilibrated magmas.

Figure DR3: Assessment of crustal interaction. Blue Ridge crustal basement from Pettingill et al. (1984) and Sinha et al. (1996). Local MORB samples collected offshore of the VA Eocene magmas from Janney et al. (2001). All samples are corrected to the average eruptive age of the VA Eocene magmatism, 50Ma. The blue lines represent AFC modeling crystallization modeling (DePaolo, 1981) of sample TK5 and a representative crustal end-member. Every tick mark represents $\mathrm{F}=0.1$, for a maximum $\mathrm{F}=1$. The rate of assimilation to crystallization $(\mathrm{R}=\mathrm{dMa} / \mathrm{dFc})$ of 0.5 . The black lines represent mixing between MORB and HIMU sources. 
Figure DR1
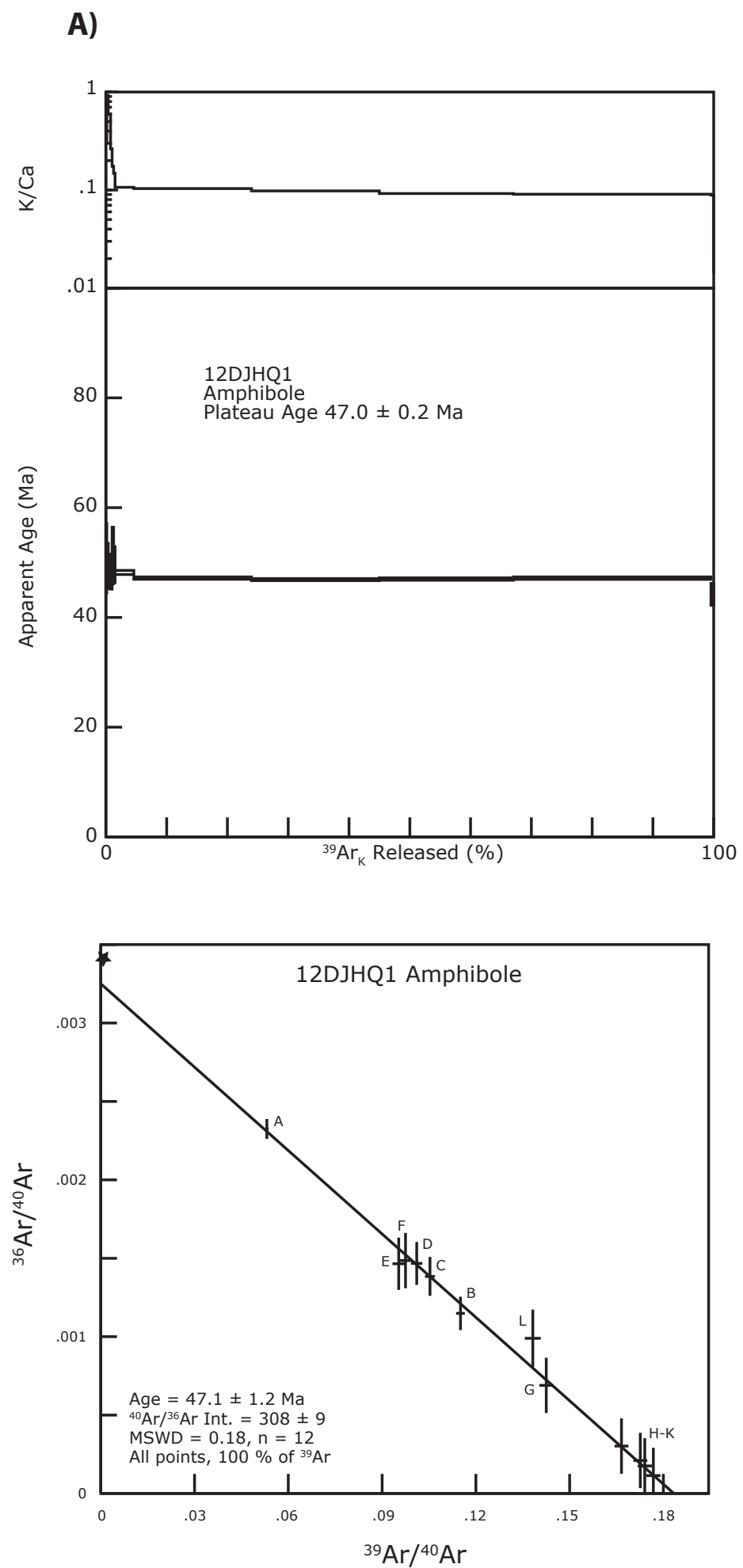
B)

DRBB-66 Amphibole

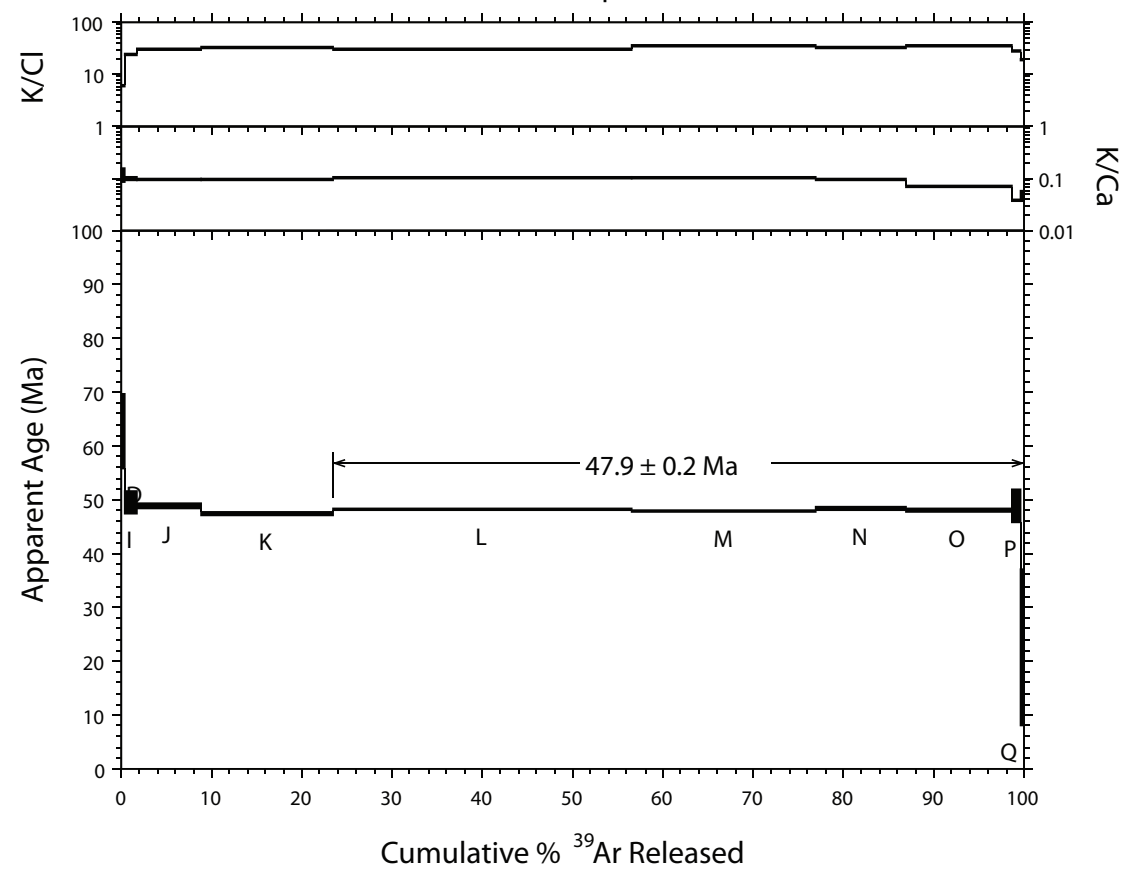

DRBB-066 Amphibole

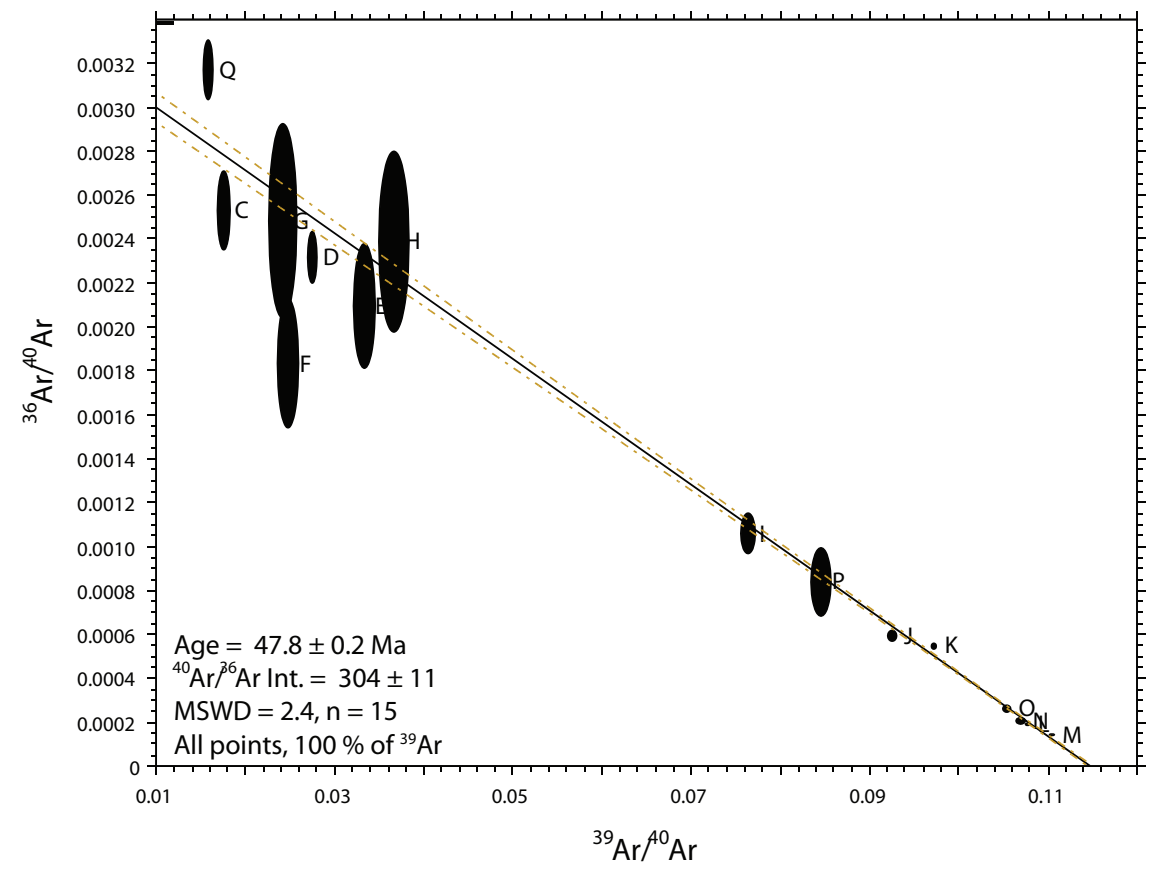


C)
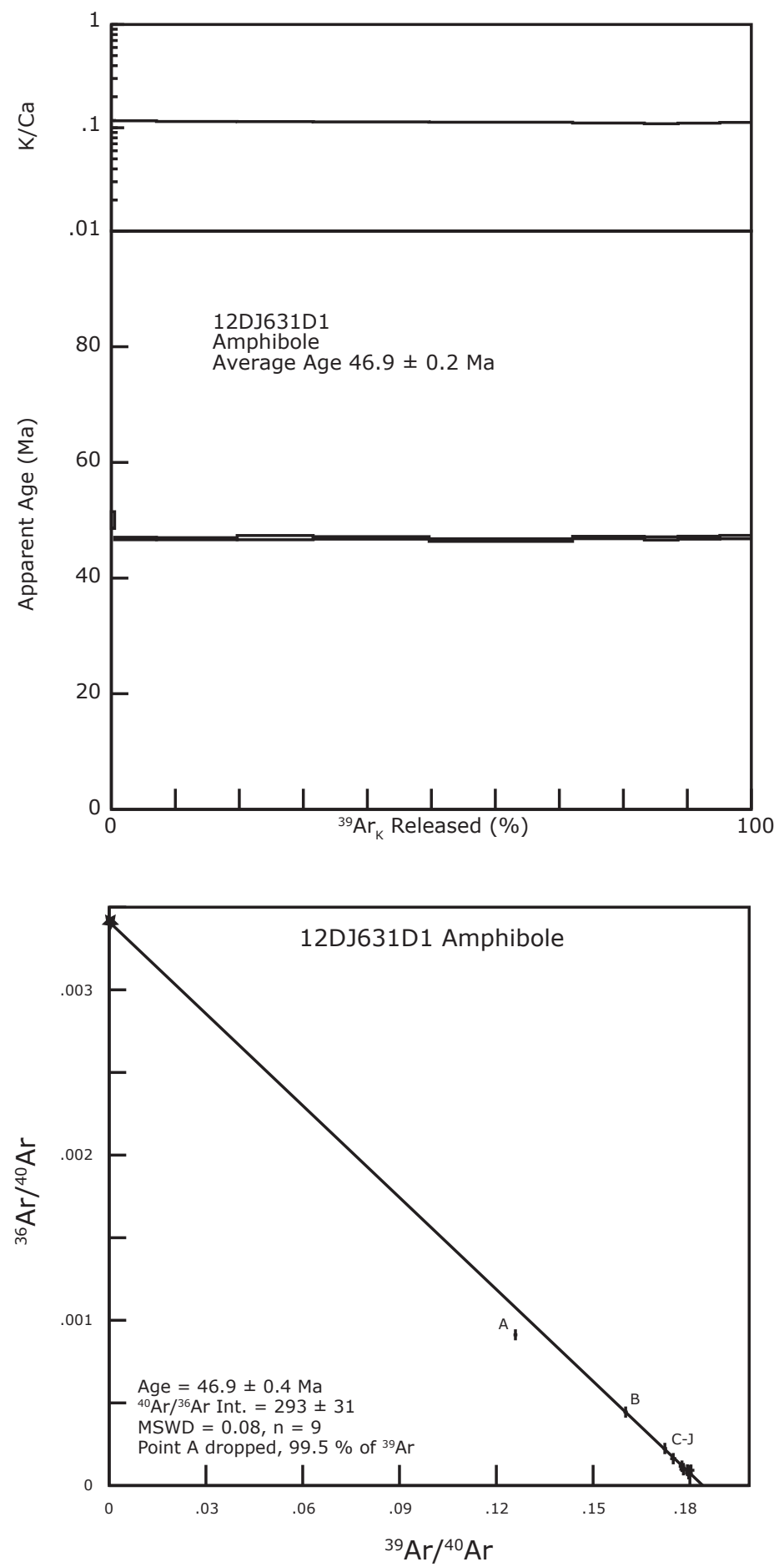


\section{D)}
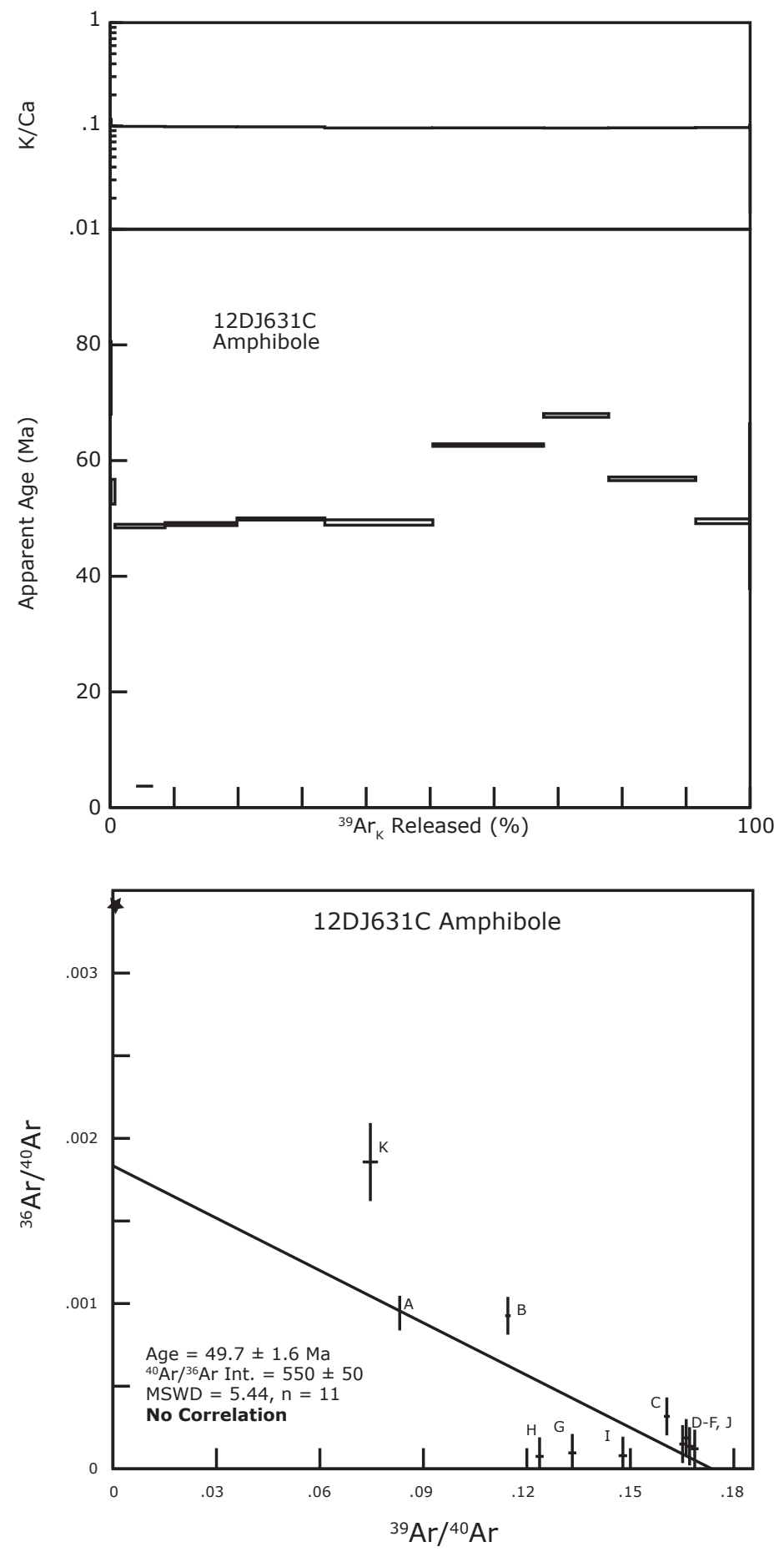
E)
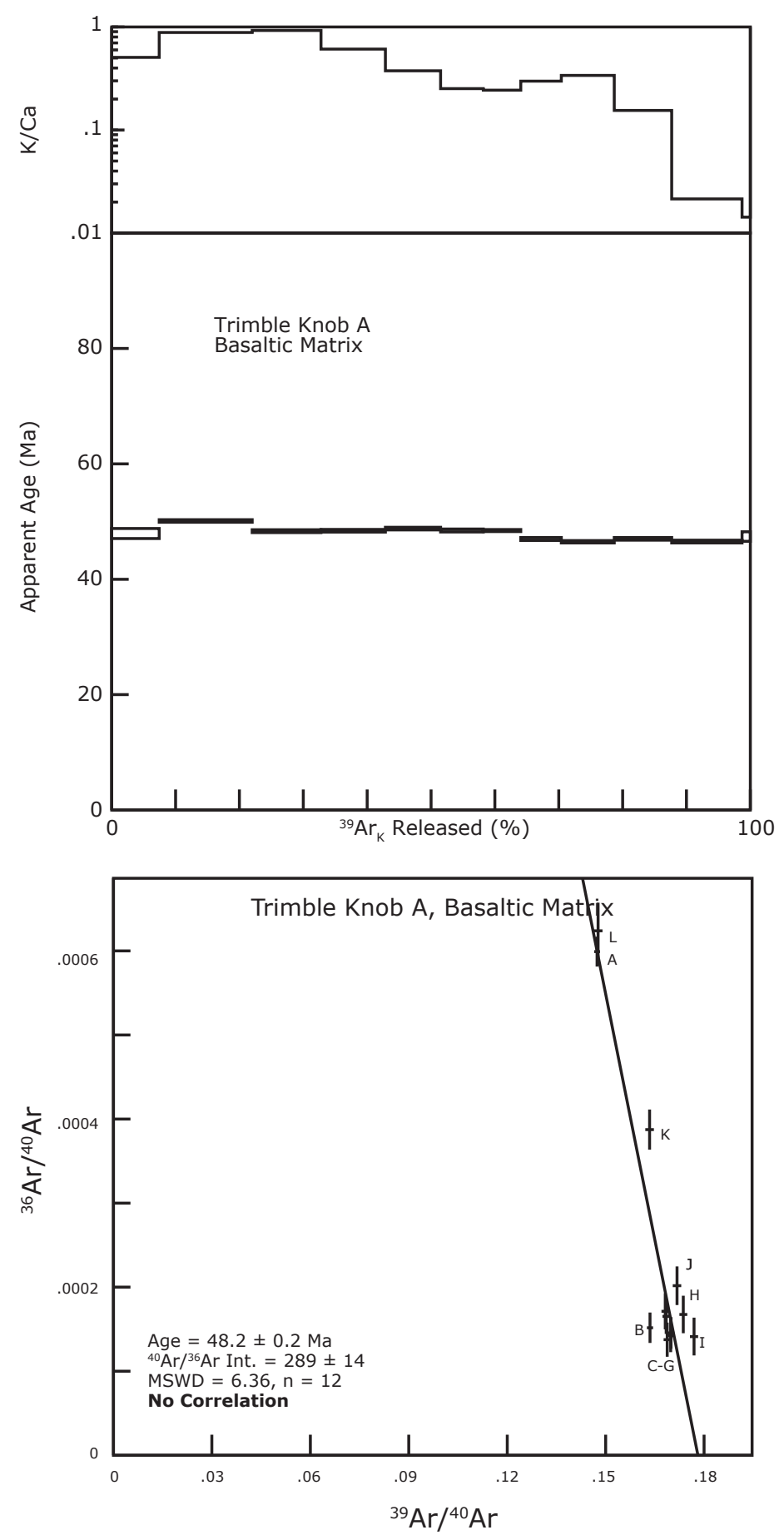
Figure DR2. Garnet in Residue

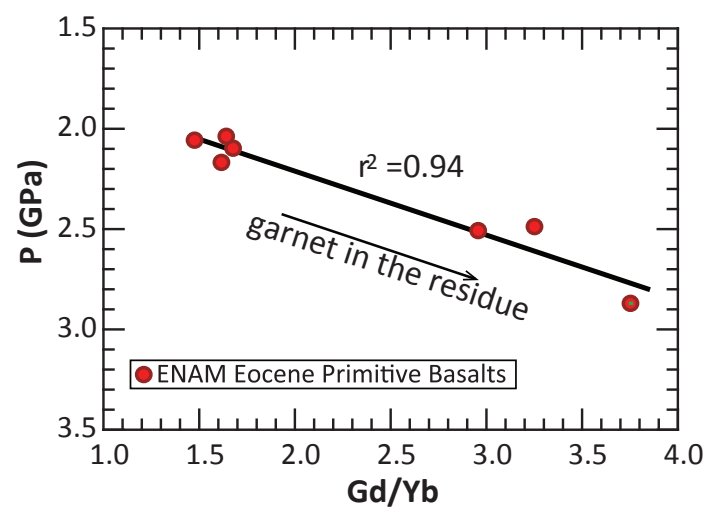



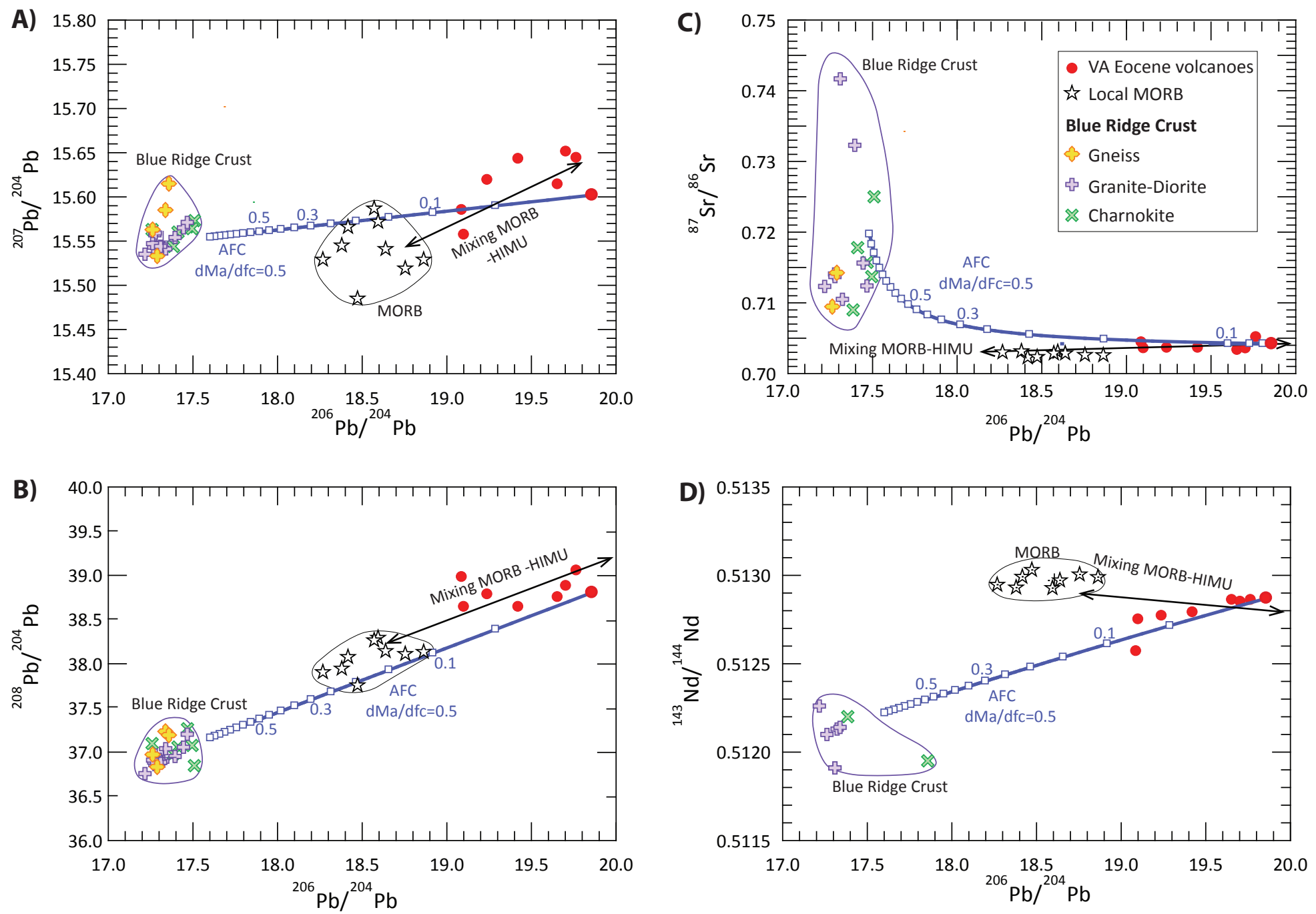


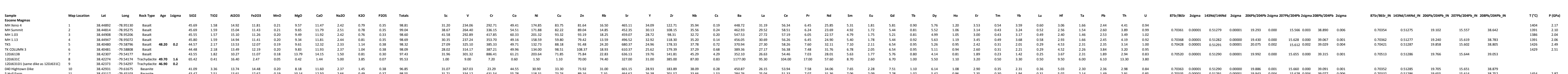

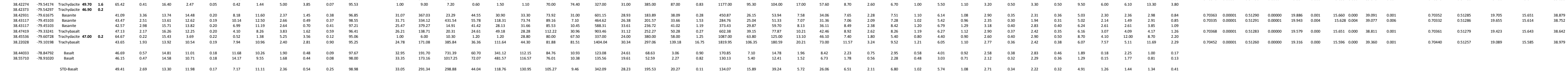




\begin{tabular}{|c|c|c|c|c|c|c|c|c|c|}
\hline Step & $\begin{array}{c}\text { Temperature } \\
\text { (C) }\end{array}$ & $\begin{array}{c}{ }^{39} \mathbf{A r} \\
(\% \text { of total) }\end{array}$ & $\begin{array}{c}\text { Radiogenic Yield } \\
(\%)\end{array}$ & $\begin{array}{c}{ }^{39} \mathbf{A r}_{\mathbf{k}} \\
(\text { moles })\end{array}$ & ${ }^{40} \mathrm{Ar}^{*} /{ }^{39} \mathrm{Ar}_{\mathbf{k}}$ & K/Ca & $\mathbf{K} / \mathbf{C l}$ & $\begin{array}{l}\text { Age } \\
(M a)\end{array}$ & $\begin{array}{c}\text { Error } \\
(M a)\end{array}$ \\
\hline \multicolumn{10}{|c|}{ Sample:12DJHQ1 Amphibole 286KD57; $J=0.004846 \pm 0.25 \%, w t .=0.1995 \mathrm{~g}$} \\
\hline A & 700 & 0.1 & 31.3 & 2.27E-15 & 5.892 & 0.31 & 23 & 50.79 & 3.16 \\
\hline B & 800 & 0.2 & 66.1 & 3.95E-15 & 5.740 & 0.93 & 48 & 49.50 & 2.01 \\
\hline $\mathrm{C}$ & 900 & 0.4 & 59.1 & 6.43E-15 & 5.611 & 0.59 & 43 & 48.39 & 1.57 \\
\hline $\mathrm{D}$ & 950 & 0.3 & 56.6 & $4.22 \mathrm{E}-15$ & 5.604 & 0.26 & 22 & 48.34 & 1.59 \\
\hline $\mathrm{E}$ & 1000 & 0.2 & 56.7 & $3.88 E-15$ & 5.950 & 0.18 & 14 & 51.28 & 2.57 \\
\hline $\mathrm{F}$ & 1050 & 0.3 & 56.1 & 4.10E-15 & 5.754 & 0.15 & 12 & 49.61 & 1.64 \\
\hline $\mathrm{G}$ & 1100 & 3.1 & 79.6 & $5.06 \mathrm{E}-14$ & 5.587 & 0.11 & 9 & 48.19 & 0.19 \\
\hline $\mathrm{H}$ & 1150 & 19.4 & 91.1 & $3.18 \mathrm{E}-13$ & 5.467 & 0.10 & 10 & 47.17 & 0.11 \\
\hline I & 1175 & 21.0 & 93.8 & $3.45 E-13$ & 5.433 & 0.10 & 11 & 46.88 & 0.09 \\
\hline $\mathrm{J}$ & 1200 & 22.0 & 94.8 & 3.62E-13 & 5.447 & 0.09 & 12 & 47.00 & 0.11 \\
\hline K & 1250 & 32.5 & 96.6 & 5.34E-13 & 5.465 & 0.09 & 12 & 47.16 & 0.11 \\
\hline $\mathrm{L}$ & 1300 & 0.4 & 70.7 & 7.30E-15 & 5.119 & 0.09 & 11 & 44.20 & 0.99 \\
\hline Total Gas & & & 93.3 & $1.64 \mathrm{E}-12$ & 5.461 & 0.10 & 12 & 47.12 & \\
\hline \multicolumn{6}{|c|}{$95.0 \%$ gas released on plateau in steps $\mathrm{H}-\mathrm{K}$} & \multicolumn{4}{|c|}{ Plateau Age $=47.0 \pm 0.2$} \\
\hline
\end{tabular}

\begin{tabular}{|c|c|c|c|c|c|c|c|c|c|}
\hline Step & $\begin{array}{c}\text { Temperature } \\
\text { (C) }\end{array}$ & $\begin{array}{c}{ }^{39} \mathbf{A r} \\
\text { (\% of total) }\end{array}$ & $\begin{array}{c}\text { Radiogenic Yield } \\
(\%)\end{array}$ & $\begin{array}{c}{ }^{39} \mathbf{A r}_{\mathbf{k}} \\
\text { (moles) }\end{array}$ & ${ }^{40} \mathrm{Ar}^{*} /{ }^{39} \mathrm{Ar}_{\mathbf{k}}$ & $\mathbf{K} / \mathbf{C a}$ & $\mathbf{K} / \mathbf{C l}$ & $\begin{array}{l}\text { Age } \\
(M a)\end{array}$ & $\begin{array}{c}\text { Error } \\
(M a)\end{array}$ \\
\hline \multicolumn{10}{|c|}{ DRBB-066 amphibole $121 \mathrm{KD} 55 ; \mathrm{J}=0.003079 \pm 0.25 \%, w t .=0.0146 \mathrm{~g}$} \\
\hline $\mathrm{C}$ & 900 & 0.2 & 25.4 & $1.68 \mathrm{E}-16$ & 14.350 & 0.04 & 4 & 78.00 & \#\#\#\# \\
\hline $\mathrm{D}$ & 1000 & 0.4 & 31.6 & $4.41 \mathrm{E}-16$ & 11.471 & 0.12 & 6 & 62.62 & 7.04 \\
\hline $\mathrm{E}$ & 1050 & 0.2 & 38.2 & $1.93 \mathrm{E}-16$ & 11.432 & 0.29 & 7 & 62.41 & \#\#\#\# \\
\hline $\mathrm{F}$ & 1100 & 0.1 & 46.0 & $1.41 \mathrm{E}-16$ & 18.421 & 0.15 & 8 & 99.53 & \#\#\#\# \\
\hline G & 1125 & 0.1 & 26.8 & 8.64E-17 & 11.081 & 0.05 & 8 & 60.53 & \#\#\#\# \\
\hline $\mathrm{H}$ & 1150 & 0.1 & 29.5 & $1.47 \mathrm{E}-16$ & 8.038 & 0.09 & 11 & 44.11 & \#\#\#\# \\
\hline I & 1175 & 1.4 & 68.9 & $1.36 \mathrm{E}-15$ & 9.002 & 0.10 & 24 & 49.32 & 2.10 \\
\hline $\mathrm{J}$ & 1200 & 7.1 & 82.6 & $7.04 \mathrm{E}-15$ & 8.909 & 0.10 & 31 & 48.82 & 0.52 \\
\hline $\mathrm{K}$ & 1225 & 14.6 & 83.9 & $1.44 \mathrm{E}-14$ & 8.624 & 0.10 & 33 & 47.28 & 0.25 \\
\hline $\mathrm{L}$ & 1250 & 33.1 & 94.5 & $3.27 E-14$ & 8.765 & 0.10 & 30 & 48.04 & 0.14 \\
\hline M & 1275 & 20.4 & 96.0 & $2.02 \mathrm{E}-14$ & 8.692 & 0.10 & 35 & 47.65 & 0.19 \\
\hline $\mathrm{N}$ & 1300 & 9.8 & 94.1 & $9.72 \mathrm{E}-15$ & 8.782 & 0.09 & 33 & 48.14 & 0.33 \\
\hline $\mathrm{O}$ & 1350 & 11.9 & 92.3 & $1.17 \mathrm{E}-14$ & 8.743 & 0.07 & 34 & 47.92 & 0.27 \\
\hline $\mathrm{P}$ & 1450 & 0.9 & 75.3 & $9.32 \mathrm{E}-16$ & 8.891 & 0.04 & 29 & 48.72 & 3.02 \\
\hline $\mathrm{Q}$ & 1650 & 0.2 & 6.5 & $2.34 \mathrm{E}-16$ & 4.070 & 0.05 & 19 & 22.47 & \#\#\#\# \\
\hline Total Gas & & & 90.7 & $9.94 \mathrm{E}-14$ & 8.772 & 0.10 & 32 & 47.92 & \\
\hline \multicolumn{6}{|c|}{$76.4 \%$ gas released on plateau in steps L-Q } & \multicolumn{4}{|c|}{ Plateau Age $=47.9 \pm 0.2$} \\
\hline
\end{tabular}




\begin{tabular}{|c|c|c|c|c|c|c|c|c|c|}
\hline Step & $\begin{array}{c}\text { Temperature } \\
\text { (C) }\end{array}$ & $\begin{array}{c}{ }^{39} \mathrm{Ar} \\
\text { (\% of total) }\end{array}$ & $\begin{array}{c}\text { Radiogenic Yield } \\
(\%)\end{array}$ & $\begin{array}{l}{ }^{39} \mathbf{A r}_{\mathbf{k}} \\
\text { (moles) }\end{array}$ & ${ }^{40} \mathrm{Ar}^{*} /{ }^{39} \mathrm{Ar}_{\mathrm{k}}$ & K/Ca & $\mathbf{K} / \mathbf{C l}$ & $\begin{array}{l}\text { Age } \\
(M a)\end{array}$ & $\begin{array}{l}\text { Error } \\
(M a)\end{array}$ \\
\hline \multicolumn{10}{|c|}{ DRBB-066 amphibole $121 \mathrm{KD} 55 ; \mathrm{J}=0.003079 \pm 0.25 \%, w t .=0.0146 \mathrm{~g}$} \\
\hline $\mathrm{C}$ & 900 & 0.2 & 25.4 & $1.68 \mathrm{E}-16$ & 14.350 & 0.04 & 4 & 78.00 & \#\#\#\# \\
\hline $\mathrm{D}$ & 1000 & 0.4 & 31.6 & $4.41 \mathrm{E}-16$ & 11.471 & 0.12 & 6 & 62.62 & 7.04 \\
\hline $\mathrm{E}$ & 1050 & 0.2 & 38.2 & 1.93E-16 & 11.432 & 0.29 & 7 & 62.41 & \#\#\# \\
\hline $\mathrm{F}$ & 1100 & 0.1 & 46.0 & $1.41 \mathrm{E}-16$ & 18.421 & 0.15 & 8 & 99.53 & \#\#\# \\
\hline G & 1125 & 0.1 & 26.8 & 8.64E-17 & 11.081 & 0.05 & 8 & 60.53 & \#\#\# \\
\hline $\mathrm{H}$ & 1150 & 0.1 & 29.5 & $1.47 \mathrm{E}-16$ & 8.038 & 0.09 & 11 & 44.11 & \#\#\# \\
\hline I & 1175 & 1.4 & 68.9 & $1.36 \mathrm{E}-15$ & 9.002 & 0.10 & 24 & 49.32 & 2.10 \\
\hline $\mathrm{J}$ & 1200 & 7.1 & 82.6 & 7.04E-15 & 8.909 & 0.10 & 31 & 48.82 & 0.52 \\
\hline K & 1225 & 14.6 & 83.9 & $1.44 \mathrm{E}-14$ & 8.624 & 0.10 & 33 & 47.28 & 0.25 \\
\hline $\mathrm{L}$ & 1250 & 33.1 & 94.5 & 3.27E-14 & 8.765 & 0.10 & 30 & 48.04 & 0.14 \\
\hline M & 1275 & 20.4 & 96.0 & 2.02E-14 & 8.692 & 0.10 & 35 & 47.65 & 0.19 \\
\hline $\mathrm{N}$ & 1300 & 9.8 & 94.1 & $9.72 \mathrm{E}-15$ & 8.782 & 0.09 & 33 & 48.14 & 0.33 \\
\hline $\mathrm{O}$ & 1350 & 11.9 & 92.3 & $1.17 \mathrm{E}-14$ & 8.743 & 0.07 & 34 & 47.92 & 0.27 \\
\hline $\mathrm{P}$ & 1450 & 0.9 & 75.3 & 9.32E-16 & 8.891 & 0.04 & 29 & 48.72 & 3.02 \\
\hline Q & 1650 & 0.2 & 6.5 & 2.34E-16 & 4.070 & 0.05 & 19 & 22.47 & \#\#\# \\
\hline Total Gas & & & 90.7 & $9.94 \mathrm{E}-14$ & 8.772 & 0.10 & 32 & 47.92 & \\
\hline \multicolumn{6}{|c|}{$76.4 \%$ gas released on plateau in steps L-Q } & \multicolumn{4}{|c|}{ lateau Age $=47.9 \pm 0.2$} \\
\hline
\end{tabular}

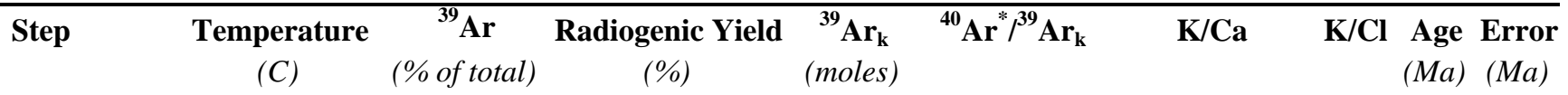

Sample:12DJ631D1 Amphibole 270KD57; $J=0.004849 \pm 0.25 \%$, wt. $=0.1951 \mathrm{~g}$

$\begin{array}{llllllllll}\text { A } & 1050 & 0.5 & 73.0 & 1.13 \mathrm{E}-14 & 5.800 & 0.12 & 11 & 50.03 & 0.73 \\ \mathrm{~B} & 1075 & 6.6 & 86.9 & 1.44 \mathrm{E}-13 & 5.426 & 0.12 & 11 & 46.85 & 0.11 \\ \mathrm{C} & 1100 & 12.6 & 93.4 & 2.76 \mathrm{E}-13 & 5.421 & 0.12 & 11 & 46.80 & 0.09 \\ \mathrm{D} & 1125 & 11.9 & 95.2 & 2.61 \mathrm{E}-13 & 5.443 & 0.11 & 11 & 47.00 & 0.18 \\ \mathrm{E} & 1150 & 18.1 & 96.5 & 3.97 \mathrm{E}-13 & 5.438 & 0.11 & 11 & 46.95 & 0.10 \\ \mathrm{~F} & 1175 & 22.4 & 97.3 & 4.92 \mathrm{E}-13 & 5.393 & 0.11 & 11 & 46.57 & 0.11 \\ \mathrm{G} & 1200 & 11.2 & 97.8 & 2.45 \mathrm{E}-13 & 5.445 & 0.11 & 11 & 47.01 & 0.10 \\ \mathrm{H} & 1225 & 5.3 & 97.3 & 1.16 \mathrm{E}-13 & 5.427 & 0.11 & 11 & 46.86 & 0.14 \\ \mathrm{I} & 1250 & 6.5 & 97.8 & 1.43 \mathrm{E}-13 & 5.442 & 0.11 & 11 & 46.99 & 0.12 \\ \text { J } & 1350 & 4.9 & 97.1 & 1.08 \mathrm{E}-13 & 5.454 & 0.11 & 11 & 47.09 & 0.15 \\ \text { Total Gas } & & & & & & & & & \\ \end{array}$


Mazza et al., 2014

Table DR2

\begin{tabular}{|c|c|c|c|c|c|c|c|c|c|}
\hline Step & $\begin{array}{c}\text { Temperature } \\
\text { (C) }\end{array}$ & $\begin{array}{c}{ }^{39} \mathrm{Ar} \\
\text { (\% of total) }\end{array}$ & $\begin{array}{c}\text { Radiogenic Yield } \\
(\%)\end{array}$ & $\begin{array}{l}{ }^{39} \mathbf{A r}_{\mathbf{k}} \\
\text { (moles) }\end{array}$ & ${ }^{40} \mathrm{Ar}^{*} /{ }^{39} \mathrm{Ar}_{\mathrm{k}}$ & K/Ca & $\mathbf{K} / \mathbf{C l}$ & $\begin{array}{l}\text { Age } \\
(M a)\end{array}$ & $\begin{array}{l}\text { Error } \\
(M a)\end{array}$ \\
\hline \multicolumn{10}{|c|}{ Sample:12DJ631C Amphibole 272KD57; $J=0.004846 \pm 0.25 \%, w t .=0.1950 \mathrm{~g}$} \\
\hline A & 1050 & 0.2 & 72.1 & 2.99E-15 & 8.678 & 0.12 & 7 & 74.31 & 3.14 \\
\hline B & 1075 & 0.6 & 72.6 & $1.07 \mathrm{E}-14$ & 6.343 & 0.10 & 6 & 54.62 & 1.07 \\
\hline C & 1100 & 7.8 & 90.6 & $1.42 \mathrm{E}-13$ & 5.644 & 0.10 & 6 & 48.67 & 0.15 \\
\hline D & 1125 & 11.2 & 94.5 & $2.04 \mathrm{E}-13$ & 5.684 & 0.10 & 7 & 49.02 & 0.13 \\
\hline E & 1150 & 13.7 & 95.6 & 2.49E-13 & 5.787 & 0.10 & 7 & 49.89 & 0.09 \\
\hline $\mathrm{F}$ & 1175 & 16.9 & 96.4 & 3.07E-13 & 5.716 & 0.10 & 7 & 49.29 & 0.23 \\
\hline G & 1200 & 17.3 & 97.2 & 3.14E-13 & 7.295 & 0.10 & 7 & 62.67 & 0.11 \\
\hline $\mathrm{H}$ & 1225 & 10.2 & 97.8 & $1.85 \mathrm{E}-13$ & 7.904 & 0.10 & 7 & 67.81 & 0.16 \\
\hline I & 1250 & 13.6 & 97.7 & $2.47 \mathrm{E}-13$ & 6.606 & 0.10 & 7 & 56.85 & 0.16 \\
\hline $\mathrm{J}$ & 1350 & 8.4 & 96.0 & $1.53 \mathrm{E}-13$ & 5.741 & 0.10 & 7 & 49.51 & 0.20 \\
\hline K & 1450 & 0.1 & 45.1 & $1.87 \mathrm{E}-15$ & 6.048 & 0.10 & 7 & 52.11 & 7.12 \\
\hline Total Gas & & & 95.8 & $1.82 \mathrm{E}-12$ & 6.344 & 0.10 & 7 & 54.63 & \\
\hline Step & $\begin{array}{c}\text { Temperature } \\
(C) \\
\end{array}$ & $\begin{array}{l}\text { No Plateau } \\
{ }^{39} \mathrm{Ar} \\
\text { (\% of total) } \\
\end{array}$ & $\begin{array}{c}\text { Radiogenic Yield } \\
(\%)\end{array}$ & $\begin{array}{c}\begin{array}{c}{ }^{39} \mathbf{A r}_{\mathbf{k}} \\
\text { (moles) }\end{array} \\
\end{array}$ & ${ }^{40} \mathrm{Ar}^{*} /{ }^{39} \mathrm{Ar}_{\mathrm{k}}$ & K/Ca & $\mathbf{K} / \mathbf{C l}$ & $\begin{array}{l}\text { Age } \\
(M a) \\
\end{array}$ & $\begin{array}{c}\text { Error } \\
(M a) \\
\end{array}$ \\
\hline \multicolumn{10}{|c|}{ Sample:Trimble Knob A Amphibole 278KD57; J = 0.004821 $\pm 0.25 \%, w t .=0.1900 \mathrm{~g}$} \\
\hline A & 700 & 7.4 & 82.3 & $1.69 \mathrm{E}-13$ & 5.584 & 0.51 & 38 & 47.92 & 0.43 \\
\hline B & 800 & 14.6 & 95.5 & 3.32E-13 & 5.842 & 0.88 & 68 & 50.10 & 0.11 \\
\hline $\mathrm{C}$ & 850 & 10.8 & 95.7 & $2.46 \mathrm{E}-13$ & 5.633 & 0.93 & 61 & 48.33 & 0.12 \\
\hline $\mathrm{D}$ & 900 & 10.1 & 95.8 & $2.30 \mathrm{E}-13$ & 5.641 & 0.61 & 49 & 48.41 & 0.11 \\
\hline $\mathrm{E}$ & 950 & 8.7 & 95.9 & $1.97 \mathrm{E}-13$ & 5.685 & 0.38 & 63 & 48.78 & 0.12 \\
\hline F & 1000 & 6.7 & 95.1 & $1.52 \mathrm{E}-13$ & 5.647 & 0.25 & 111 & 48.45 & 0.13 \\
\hline G & 1050 & 5.9 & 94.9 & $1.34 \mathrm{E}-13$ & 5.646 & 0.24 & 174 & 48.44 & 0.09 \\
\hline $\mathrm{H}$ & 1100 & 6.4 & 95.1 & $1.45 \mathrm{E}-13$ & 5.473 & 0.30 & 276 & 46.98 & 0.13 \\
\hline I & 1150 & 8.3 & 95.8 & 1.89E-13 & 5.416 & 0.34 & 469 & 46.50 & 0.10 \\
\hline $\mathrm{J}$ & 1200 & 9.0 & 94.0 & 2.05E-13 & 5.476 & 0.15 & 191 & 47.01 & 0.11 \\
\hline K & 1250 & 11.0 & 88.6 & $2.51 \mathrm{E}-13$ & 5.420 & 0.02 & 112 & 46.54 & 0.12 \\
\hline $\mathrm{L}$ & 1350 & 1.3 & 81.6 & 2.97E-14 & 5.522 & 0.01 & 106 & 47.40 & 0.41 \\
\hline Total Gas & & & 93.5 & $2.28 \mathrm{E}-12$ & 5.600 & 0.45 & 135 & 48.05 & \\
\hline & & No Plateau & & & & & & & \\
\hline
\end{tabular}

